\title{
SENSORY DISTURBANCES IN CORTICAL WOUNDS WITH SPECIAL REFERENCE TO PAIN
}

\author{
BY
}

\author{
JOHN MARSHALL
}

\author{
From the Military Hospital, Wheatley, and Department of Neurology, United Oxford Hospitals
}

The role of the cortex in the appreciation of the various forms of sensation has been of interest to neurologists for many years. Towards the latter part of the nineteenth century a vast amount of work on the functions of the cerebral cortex was done by clinical workers and by the experimental physiologists. From these studies there emerged three schools of thought. The first was mainly represented by Ferrier (1886), who, from his observations on the effect of extirpation of the corlex in the experimental animal, concluded "that the thus produced affection is a purely motor one, and the centres or regions in question are strictly motor". Schäfer (1898) took a similar view.

The second school supported by Munk (1892) and Mott (1894) maintained that the Rolandic area was primarily sensory, and registered impressions occasioned by movements. The last view was that originally proposed by Hughlings Jackson, and adopted by Horsley in his Linacre Lecture of 1909 , namely, that the Rolandic region was in reality sensori-motor. The difficulties which prevented the reconciliation of these various schools were many, not the least being confusion with regard to the terms used. Campbell's classical work in 1905 clarified the situation by demonstrating that the pre- and post-central convolutions differed in structure, a point already illustrated by Birt (1904), when he described a circumscribed lesion of the post-central convolution with no impairment of motor function.

Though the main concern of the observers of this period was with tactile sensibility the problem of the localization of pain sensibility was not ignored. Hitzig (1900) stated categorically that pain sensation was formed subcortically. On the other hand, Russel and Horsley (1906) reported a case of pachymeningitis of the cortex in which the cortex was excised posterior to the fissure of Rolando to a depth of $2 \mathrm{~cm}$. This patient showed marked analgesia and loss of temperature sense. Three years later Horsley (1909) said :

" The evidence I possess on the question would seem to show that the conscious appreciation of pain in the upper limb is partly represented in the postcentral gyrus. After free removal or destruction of the whole arm centre-that is both central gyri-it is notably diminished, though like all forms of sensation not totally abolished."

So by the end of the first decade of this century the present conception of the post-central gyrus as the great sensory projection area had been evolved. The next year but one after this publication marked the appearance of the classical studies of Head and Holmes (1911) which will form the basis of the subsequent discussion. They considered that the thalamus has two functional parts. There is first a receptive centre in the lateral nucleus where all sensory fibres terminate. From here fibres are divided into two major groups, the one subserving position sense and discriminative forms of sensibility which are passed on directly to the cortex, the other subserving pain, heat, cold, and gross touch which are relayed to the grey matter of the thalamus to a physiological station which they termed the essential organ of the thalamus. Here the effects of these impulses enter consciousness. Though they have no representation in the cerebral cortex, they are not entirely free from cerebral control, however, for in the normal person the response to pain does not have the excessive, explosive character of those with thalamic lesions. This is due to the exercise of cortical control which conditions the thalamic response just as Head (1920) visualized epicritic sensation to control the response to protopathic forms of sensibility. In thalamic lesions, however, the control is removed and the excessive response to unpleasant stimuli becomes manifest.

There are, however, many difficulties inherent in this hypothesis. Objection was raised that if the 
thalamic over-response was due to loss of cortical control, it should equally appear in cortical lesions which remove the source of this control. This objection was met by the supposition that, as fibres come from all parts of the cortex to the thalamus, the lesion must be situated near their end point in order to remove completely cortical control. Interruption of a portion of the fibres only, as must occur in a cortical lesion, was insufficient to permit the thalamus to manifest itself in its uninhibited state. Further, since they believed that this altered pain sensation was entering consciousness in the thalamus, it followed that the receptor centre and the essential organ must be intact, or at least largely so. No such anatomical divisions as the receptor centre and the essential organ have been demonstrated. Hence we are asked to visualize a lesion in the lateral part of the thalamus which cuts thalamo-cortical fibres completely but spares the fibres from the fillets entering the thalamus and the cell stations comprising the "essential organ". Any attempt to establish the medial nucleus of the thalamus as a discrete " essential organ" for pain sensibility was prevented by the observation of Smyth and Stern (1938) that lesions confined to this part of the thalamus produced no sensory changes at all.

A further blow was struck by the work of Le Gros Clark (1932) who showed that when the cortex is removed there follows complete degeneration of the grey matter of the lateral part of the thalamus. As has already been pointed out, Head and Holmes maintained that all cortical fibres must be cut to enable the thalamic syndrome to appear. Where then, when complete degeneration of the cells of the thalamus has occurred, lies the essential organ? Despite these weighty objections it became generally accepted and a part of classical neurological belief that sensibility to pain, heat, cold, and gross touch are not represented in the cortex but have their end station in the thalamus where these forms of sensation enter conscíousness. Yet a more careful perusal of the later works of Head and Holmes raises the suspicion that perhaps they did not feel the conviction on this matter that their work appears to have carried.

These doubts are plainly manifest in Studies in Neurology (Head, 1920). Thus he wrote (page 665) :

"But, although, the appeal of all such aspects of sensibility (pain) is overwhelmingly thalamic it must not be forgotten that pain can be roughly graded according to the intensity of the stimulus ; in so far, it is the product of cortical activity."

And later in summarizing his section on the " measured prick" :
"Thus we can sum up as follows our present experience of the effect produced by a cerebral injury upon sensations of pricking.

(1) A gross subcortical lesion tends to raise the threshold to measured pricks distinctly, but not to an extreme degree.

(2) Injury to the cortex, uncomplicated by destruction of subcortical tissues, does not tend to raise the threshold materially. But it may produce a profound difference in character of the sensation; this is due, in great part, to disturbance of that aspect of discrimination sometimes called the 'sense of a point'.

(3) Cortical activity, however, probably exercises a distinct influence even over the appreciation of the relative intensity of successive pricks. But this is so slight that it was not measurable in most of the cases of injury extending over a comparatively small area which formed the basis of this research."

The difficulty of this question as to whether pain sensibility can be abolished or even profoundly affected by cortical lesions is manifest by the fact that German observers were taking an entirely opposed view at this time. The best account of these is undoubtedly contained in the work of Kleist (1922). His conclusions were based on observations made on head wounds of the 1914-18 war, and he postulated that pain and temperature sensation are represented in the front part of the post-central convolution. A further observation was that not only could pain and temperature be decreased but that an excessive response could appear, as a result of a cortical lesion. He found that in these cases there is usually associated diminution of position sense, discrimination and localization, and, therefore, he supposed that while the areas for these latter forms of sensibility were destroyed the neighbouring areas for pain and temperature were being irritated. Moreover he discovered that this response to the pin-prick in these cases had lost its pointed nature and was diffuse and unpleasant, and he suggested that the release of this so-called protopathic form of sensibility of Head (1920) could occur in central as well as in peripheral lesions.

Nor were the Germans alone in this viewpoint, for the French school was taking a similar view. As early as 1915 Dejerine and Mouzon reported the case of a lieutenant with a small cortical wound and loss of pain sensibility in the contralateral arm. Then in 1923 Piéron published his book, Le cerveau et la pensée in which he reviewed French wartime experiences with cortical wounds. $\mathrm{He}$ attributed to various forms of sensation a coefficient running from 1 , which was normal, to 5 , which indicated complete loss of that form of sensibility. His list of mean coefficients of the observations collected were :-

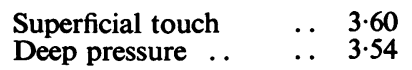


Heat and cold .. $\quad \ldots \quad 3 \cdot 21$

Pain .. .. .. 3.35

Vibration through bone 3.47

Appreciation of weight 3.75

Tactile discrimination .. $\quad 3 \cdot 80$

Tactile localization $\quad . . \quad 3 \cdot 38$

Position .. $\quad . . \quad$.. 4.00

Stereognosis $\quad . . \quad \ldots 4 \cdot 13$

From this he considered that pain sensibility could be affected by cortical wounds. Later in 1932 Guillain and Bertrand quoted the case of a woman aged 53 years, who besides experiencing spontaneous pains had hypoalgesia over the right side of the body. Post-mortem examination revealed bilateral parieto-occipital lesions, and the authors state categorically that the thalamus was not involved.

Kinnier Wilson (1927) drew attention to evidence that pain has a definite representation in the human cortex and that previous conclusions in the opposite sense must be reconsidered. Michelsen (1943) and Earl Walker (1943) held the same view. Davison and Schick (1935) described two cases of cerebral embolism with resultant softening of the postcentral and parietal convolutions. The patients had hypoalgesia and hyperpathia on the contralateral side, and careful necropsy studies established that the thalamus was not involved.

Pain as an aura in epilepsy was described as early as 1901 by Gowers in his book, Epilepsy and Other Chronic Convulsive Disorders, and has frequently been considered to favour the thesis that pain is represented in the cortex. Souques (1921) described a woman aged 23 years who had epileptic attacks beginning with severe pain in the left hand, and was found to have a psammoma lying over the right Rolandic cortex. Also Holmes (1927a) in discussing a case of left-sided sensory epilepsy wrote :

"The attacks always began with tingling in the left arm sometimes so intense as to be actually painful, and then spread slowly to the shoulder down the trunk and into the left leg."

It might have been thought that the development of electrical stimulation of the cortex in the conscious human subject as a method of investigation might have thrown light on the representation of pain in the cortex. Foerster stimulated the postcentral gyrus electrically and noted contralateral pain. Cushing (1909), however, stimulated the post-central gyrus in two patients but no pain was caused. Penfield and Gage (1933) on the other hand, reported two cases of pain following electrical stimulation of the cortex.

Later Penfield and Boldrey (1937) described further instances of pain following cortical stimulation, but wrote :

"The fact that only eleven times out of well over eight hundred responses did the patient use the word pain to describe a cortical sensation probably indicates that pain has little if any true cortical representation."

Some interesting observations on sensory disorders following cortical wounds have also been reported by Russell (1945). He found two groups of cases in post-Rolandic wounds. Those examples in which the main incidence of the damage was thought to be on the posterior bank of the central fissure-area 3 of Brodmann-suffered loss of the primary forms of sensation, namely, pain, temperature, and touch as well as the discriminative forms. The group of wounds apparently situated on the lateral aspect of the post-central convolution (areas 1 and 2), in contrast, suffered permanent loss of the discriminative forms only. He described also examples of hyperpathia in wounds confined to the cortex. He stressed, however, the difficulty of reconciling these findings with the well known fact that in gross lesions of the sensory and motor cortex, pain sensibility is usually well preserved. He wrote :

"We thus come to the apparently paradoxical finding that while limited wounds of the Rolandic area often cause permanent loss of all forms of sensation in a contralateral limb, gross injuries to the same area permanently destroy discriminative sensory functions only."

Finally the results of animal experiment, though obviously inferior to human observations, should be mentioned. In 1944 Peele reported the results of acute and chronic cortical ablations in monkeys. He found that the response to pain stimuli was impaired or absent, following ablation mainly of area 3, for a period of three weeks. In one experiment where the whole of the parietal cortex, except area 3, was removed there was hyperpathia lasting at least eight months.

\section{Material and Methods}

The material for the present work has been studied almost exclusively at the Head Injury Advice Bureau at a military hospital for head injuries, and consists of 1,000 cases of penetrating brain wounds. Amongst these, 186 cases with permanent sensory loss were found, and 43 were re-examined personally. Many of these have been excluded because of extensive wounds or frequent fits.

The 18 cases reported here have been divided into four series. From the records 25 cases of cortical wounds with impairment of pain sense were found, and of these it was possible to re-examine 10 . In addition one case (Case 10) of a penetrating wound of the 1914-18 war under the care of Dr. Ritchie Russell has been included. These 11 cases comprise Series A.

Series B consists of two examples of persistent hyperpathia following cortical injury. Records of 
eight cases in all were found, but it was only possible to examine personally three of these. Series C contains two instances of dissociation between pain and temperature sense resulting from cortical wounds, and the records of six more examples were studied. Finally, Series D is made up of two examples of more extensive brain wounds in which position sense and 2-point discrimination were lost but pain was preserved.

One additional case (Case 18), a patient of Dr. Fergus Ferguson, has been included. This patient had pain loss due to a cortical neoplasm and has been reported to exemplify the superiority of traumatic material over neoplastic in studies of this kind. This material is summarized in Table $I$.

TABLE I

SUMMARY OF TYPES OF CASES IN PRESENT SERIES

\begin{tabular}{|c|c|c|}
\hline Series & & No. of Cases \\
\hline $\mathbf{A}$ & $\begin{array}{l}\text { Cortical wounds with pain } \\
\text { impairment }\end{array}$ & 11 \\
\hline B & $\begin{array}{l}\text { Cortical wounds with hyper- } \\
\text { pathia }\end{array}$ & 2 \\
\hline C & $\begin{array}{l}\text { Cortical wounds with im- } \\
\text { pairment of temperature } \\
\text { sense but pain preserved }\end{array}$ & 2 \\
\hline D & $\begin{array}{l}\text { Extensive wounds with loss } \\
\text { of discriminative sensi- } \\
\text { bility but pain preserved }\end{array}$ & 2 \\
\hline- & $\begin{array}{l}\text { Case of cortical neoplasm } \\
\text { with pain loss }\end{array}$ & 1 \\
\hline & Total & 18 \\
\hline
\end{tabular}

Method of Examination.-Each patient had first a routine neurological examination with special attention to the integrity of the visual fields because of its value as evidence of the superficial nature of the wound. The following modalities of sensation were then tested, sense of position and passive movement, 2-point discrimination, light touch, vibration, sensibility to pinprick, temperature sense, and finally deep pain.

The senses of position and passive movement were tested by fixing the limb or digit above the joint to be tested with one hand and holding the part distal to the joint firmly at the sides with the other hand. The joint was then moved gently through the required range of movement. The angles of movement employed were $5^{\circ}$ and multiples thereof.

2-Point discrimination was tested with a pair of dividers applied simultaneously, in the case of both points, to the skin. The distance separating the points was measured accurately on a ruler and differences of $0 \cdot 1 \mathrm{~cm}$. were noted.

Vibration sense was tested with a C 128 tuning fork. The instrument was applied to the defective side, and when the patient ceased to feel it, was immediately transferred to the opposite limb and the duration of vibration on that side was noted.

Light touch was tested with light and heavy threads of nylon, which for purposes of this study are referred to as No. 1 and No. 2 respectively, with a wisp of cotton wool, and where necessary with a light touch of the finger. The skin was touched with these objects and they were not drawn along the surface. The results are recorded as the number of stimuli appreciated out of each ten stimuli.

Pin-prick was tested with an ordinary pin, but thrusts were heavy to ensure it was pain that was tested and not the sense of point. Testing colleagues has shown that in practice a constant degree of pain can be achieved by the ordinary clinical method of testing with a pin. The results were recorded as being of two grades. " Lost" was recorded when even on penetrating the epidermis the patient felt no pain but was only aware of a touch. "Gross impairment" was recorded when the patient felt slight pain on pushing a pin through the skin.

Temperature sense was tested with water in metal tubes with a thermometer to record the temperature. The patient was asked to differentiate between tubes of different temperatures applied successively to an area. In addition the same tube was applied to comparative areas on both sides of the body and the patient was asked to say if they felt the same or differently.

All the deep pain tests were made by the method employed by Kellgren (1938a) in his studies on pain arising from deep structures. An injection of $0.2 \mathrm{ml}$. of $6 \%$ sodium chloride was made into muscles. A preliminary testing was usually carried out by a pressure algesiometer in order to obtain some idea of the extent of the analgesic areas, as it was found advantageous to test these areas first with the hypertonic saline as the enthusiasm of the patient tended to wane rapidly when normal areas were injected.

\section{Case Records}

Series A.-This consisted of patients with small cortical wounds with pain impairment.

Case No. 1 (No. 10813).-This man was wounded on January 23, 1945, in the right parietal region by a sniper's bullet. He did not lose consciousness and remembers that his left arm immediately became numb and powerless. He was examined at No. 6 M.N.S.U. by Capt. P. L. M. Hartley within 24 hours. The patient was conscious and quite rational. There was a faint trace of left facial weakness. In the left arm there was complete loss of power and loss of all modalities of sensation. The legs were normal and plantar responses were flexor. He was operated upon on January 25 by Capt. J. W. Turner. There was a small depressed fracture in the right parietal region which was elevated. The dura was intact though tense, but it was not blue. The dura was left intact, and the wound excised and cleaned (Fig. 1). He was examined by Dr. G. E. Smyth on March 28, 1945. There was then deep hypalgesia of the whole of the left face with hypaesthesia also. The facial weakness was hardly discernible. The power 
at"the shoulder and elbow was $60 \%$ but in the fingers there was only a flicker of movement. On the sensory side there was hypoalgesia of the whole of the left arm with hypaesthesia and loss of temperature sense, likewise of postural sense, 2-point, vibration, and stereognosis.

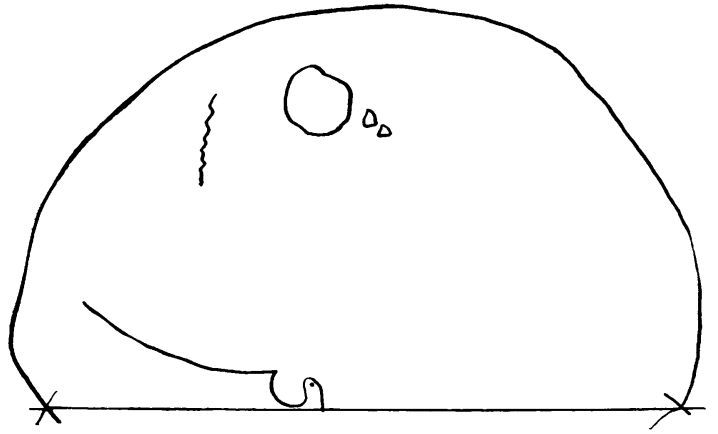

FIG. 1.-Tracing of lateral radiograph of skull showing site of wound in Case 1.

I examined him five years later on August 24, 1950. He was at work and had no fits. Visual fields were full and the cranial nerves were normal. The weakness and sensory disturbance in the face were no longer detectable. Reflexes in the left arm were increased with slight hypertonus. Power in the shoulder and elbow was still only $60 \%$ and only a flicker of movement was present in the fingers. The legs were normal. The sensory findings were :-

\begin{tabular}{|c|c|}
\hline Right Arm & Left Arm \\
\hline $\begin{array}{c}\text { Position and Passive Movement } \\
\text { Fingers } 5^{\circ} \text { correct } \\
\text { Wrist } \quad 5^{\circ} \text { correct } \\
\text { Elbow } \quad 5^{\circ} \text { correct }\end{array}$ & $\begin{array}{l}90^{\circ} \text { failed } \\
30^{\circ} \text { direction correct } \\
5^{\circ} \text { correct }\end{array}$ \\
\hline Vibration Normal & Lost \\
\hline $\begin{array}{l}\text { 2-point } \\
\text { Fingers } 0.3 \mathrm{~cm} .\end{array}$ & No threshold \\
\hline $\begin{array}{cc}\text { Touch (No. } 1 \text { nylon) } \\
\text { Fingers } & 10 / 10 \\
\text { Forearm } & 10 / 10 \\
\text { Arm } & 10 / 10\end{array}$ & $\begin{array}{l}0 / 10 \\
5 / 10 \\
10 / 10\end{array}$ \\
\hline Pin-prick Normal & $\begin{array}{l}\text { Lost left hand ; gros } \\
\text { impairment left forearm }\end{array}$ \\
\hline $\begin{aligned} \text { Temperature } & \\
22^{\circ}-33^{\circ}: & 24^{\circ}-40^{\circ} \mathrm{C} \\
& \text { Resolved }\end{aligned}$ & Not resolved \\
\hline
\end{tabular}

Deep Pain

$0.2 \mathrm{ml}$. of $6 \%$ sodium chloride was injected into identical sites of both arms. No pain was felt on the left and severe pain on the right.

Case No. 2 (No. 9683). - This man sustained a penetrating wound in the right parietal region on August 22, 1944, with momentary loss of consciousness. He was examined the next day by Capt. J. H. Paterson at
No. 6 M.N.S.U. The visual fields were full but there was weakness and loss of sensation over the left side of the face. There was considerable weakness with increase of tone and reflexes in the left arm. The leg was normal and the left plantar response equivocal. All modalities of sensation were reported lost on the left arm and neck. He was operated on by Major C. A. Calvert on August 25,1944 . There was a large dural tear and a track $3 \mathrm{~cm}$. deep containing clot (Fig. 2). The last recorded examination was made on November 7, 1944. There was greatly diminished power in the left arm with slight impairment in the leg. Reflexes were normal and plantars were flexor. Position sense and stereognosis were lost on the left, and there was hypoaesthesia and analgesia of the whole of the left side maximal in the arm and least in the foot.

I examined him on February 6, 1950. He was well and at work. Since 1946, however, he had experienced occasional attacks of loss of consciousness for a minute without convulsion. The last attack had been three months before examination. There was decreased power and increase of tone in the left arm and less so in the left leg. The reflexes and plantar responses were normal and the fields of vision were full. Sensory findings were :-

\begin{tabular}{|c|c|}
\hline Right Arm & Left Arm \\
\hline $\begin{array}{l}\text { Position and Passive Movement } \\
\text { Fingers } 5^{\circ} \text { correct } \\
\text { Elbow } \quad 5^{\circ} \text { correct }\end{array}$ & $\begin{array}{lll}90^{\circ} & \text { movement only } \\
60^{\circ} & \text { movement only }\end{array}$ \\
\hline Vibration Normal & Greatly diminished \\
\hline $\begin{array}{l}\text { 2-point } \\
\text { Fingers } \quad 0.4 \mathrm{~cm} .\end{array}$ & No threshold \\
\hline Touch (wool) $10 / 10$ & $1 / 10 \quad 2 / 10$ \\
\hline Pin-prick Normal & Gross impairment \\
\hline Temperature Normal & $\begin{array}{l}\text { Differences of } 4^{\circ} \mathrm{C} \\
\text { resolve accurately }\end{array}$ \\
\hline Right Leg & Left Leg \\
\hline $\begin{array}{l}\text { Position and Passive Movement } \\
\text { Toes } 55^{\circ} \text { correct }\end{array}$ & $90^{\circ}$ movement only \\
\hline Vibration Normal & Greatly diminished \\
\hline Touch (wool) Normal & $2 / 10$ \\
\hline Pin-prick Normal & Gross impairment \\
\hline Temperature Normal & $\begin{array}{l}\text { Resolved differences of } \\
4^{\circ} \mathrm{C} \text { slowly }\end{array}$ \\
\hline
\end{tabular}

Deep Pain

$0.2 \mathrm{ml}$. of $6 \%$ sodium chloride was injected into identical sites of both arms and legs. No pain on the left but severe pain on the right. $0 \cdot 1 \mathrm{ml}$. of $6 \%$ sodium chloride into left masseter did produce pain in area of upper molars but it was not so severe as on the right. 


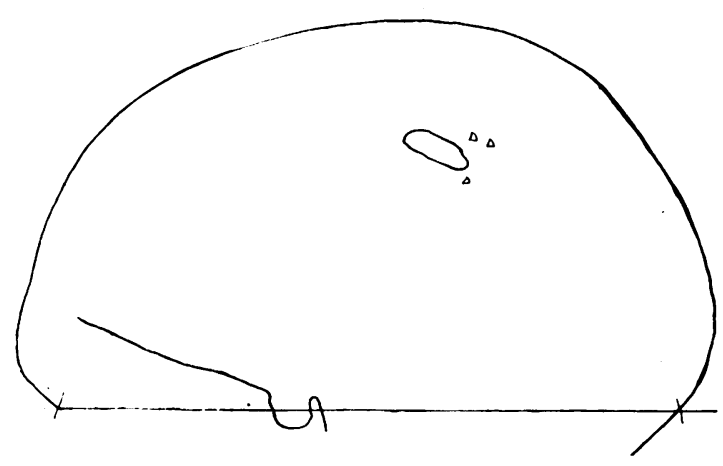

FIG. 2.-Tracing of lateral radiograph of skull showing site of wound in Case 2.

Case No. 3 (No. 10386).-This man sustained a parasagittal gunshot wound on October 26, 1944. He was unconscious for less than a minute, after which he found he could not move his left leg. He was examined some ten hours later at No. 9 British General Hospital, when both legs were found to be spastic with increased reflexes and extensor plantar responses. The left leg was extremely weak, the right leg slightly so. Postural sense was impaired in both feet, and there was hypoaesthesia of the left leg up to the level of the mid-thigh. He was operated on the following day by Lt. A. E. James. The skull was abraded, but there was no fracture. The wound was excised and closed in layers. He was examined by Dr. W. Ritchie Russell and Dr. G. E. Smyth in March, 1945. There was noted to be severe impairment of position and vibration sense in the left leg with hypoaesthesia and hypoalgesia up to mid-thigh. Pressure pain appeared to be absent in the left leg.

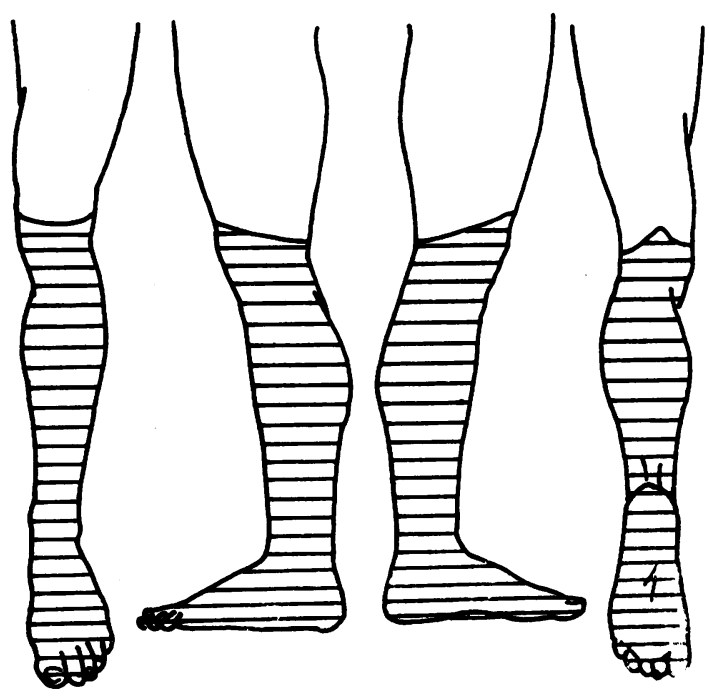

FIG. 3.-Area of gross impairment of sensibility to pin-prick in Case 3.
I examined him on November 10, 1950. He was quite well, working as a lift attendant, and had had no fits. The visual fields and cranial nerves were normal and there was no vestige of reflex, motor, or sensory abnormality in the upper limbs. In the legs there was bilateral increase of reflexes more marked on the left with increased tone in the left leg only. The right plantar was flexor, the left extensor. Power at the left knee was $80 \%$ normal, plantar flexion of the foot $60 \%$, but in the dorsiflexors there was only a flicker of movement. Sensory findings were :-

\begin{tabular}{|c|c|}
\hline Right Leg & Left Leg \\
\hline $\begin{array}{l}\text { Position and Passive Movement } \\
\text { Toes } \quad 5^{\circ} \text { correct } \\
\text { Ankle } \quad 5^{\circ} \text { correct } \\
\text { Knee } \quad 5^{\circ} \text { correct }\end{array}$ & $\begin{array}{l}90^{\circ} \text { movement only } \\
45^{\circ} \text { movement only } \\
.10^{\circ} \text { direction correct }\end{array}$ \\
\hline $\begin{array}{l}\text { Vibration } \\
\text { Ankle }\end{array}$ & Felt slightly \\
\hline $\begin{array}{l}\text { 2-point } \\
\text { Foot }\end{array}$ & No threshold \\
\hline Touch (wool) $9 / 10 \quad 9 / 10$ & $4 / 10 \quad 5 / 10 \quad 4 / 10$ \\
\hline Pin-prick & $\begin{array}{l}\text { Gross impairment (see } \\
\text { Fig. 3) }\end{array}$ \\
\hline $\begin{array}{l}\text { Temperature } \\
19^{\circ}-42^{\circ}: 32^{\circ}-37^{\circ} \mathrm{C} \\
\text { Resolved } \\
20^{\circ}, 26^{\circ} \mathrm{C} \text { Colder on right } \\
32^{\circ}, 37^{\circ} \mathrm{C} \text { Warmer on right }\end{array}$ & Resolved slowly \\
\hline
\end{tabular}

These differences extended over the same area on the left thigh as did the hypoalgesia.

Deep Pain

$0.2 \mathrm{ml}$. of $6 \%$ sodium chloride was injected into identical points in muscles of both legs. Very slight pain was felt on left but normal severe pain on right.

Case No. 4 (No. 9616).-This man was wounded in the left parietal region on August 16, 1944, by mortar fragments. He was unconscious only a few minutes but had weakness of the right arm and leg. He was operated on by Lieut. A. E. James 18 hours after the injury. There was a fracture in the left parietal region. A burr-hole was made and enlarged to remove loose bone fragments. The dura was torn and the brain bruised and lacerated. Bone chips, a foreign body, and pulped brain were removed but there was no deep track. Twelve hours after operation he was able to move his right foot. $\mathrm{He}$ continued to make an uneventful recovery. He was examined in January, 1945, when there was found to be about $50 \%$ power in the right arm with slight spasticity and increased reflexes. Power in the right leg was $80 \%$ of normal. Position sense was lost in the right hand and impaired in the right foot, and, though touch appeared normal, there was hypoalgesia in the right arm and leg.

I examined him in November, 1950. Power in the right arm was about $60 \%$ for gross movements, but fine 
finger movements were poorly performed. The right leg showed very little weakness but the foot was slightly spastic. Reflexes were slightly increased on the right side. Visual fields and cranial nerves were normal. He had no fits and was working well as a bank clerk.

Sensory findings were :-

\begin{tabular}{|c|c|}
\hline Right Arm & Left Arm \\
\hline $\begin{array}{cc}\text { Position and Passive Movement } \\
\text { Fingers } & 30^{\circ} \text { movement only } \\
\text { Wrist } & 20^{\circ} \text { movement only } \\
\text { Elbow } & 10^{\circ} \text { direction correct }\end{array}$ & $\begin{array}{l}5^{\circ} \text { correct } \\
5^{\circ} \text { correct } \\
5^{\circ} \text { correct }\end{array}$ \\
\hline Vibration Much diminished & 12 secs. longer \\
\hline 2-point $\quad$ No threshold & $0.5 \mathrm{~cm}$. correct \\
\hline $\begin{array}{l}\text { Touch }(\text { No. } 1 \text { nylon) } \\
10 / 10 \text { slightly diminished } \\
\text { subjectively }\end{array}$ & $10 / 10$ \\
\hline $\begin{array}{l}\text { Pin-prick Gross impairment } \\
\text { up to upper arm }\end{array}$ & Normal \\
\hline $\begin{array}{l}\text { Temperature } \\
\quad 15^{\circ}-29^{\circ}: 25^{\circ}-45^{\circ}: 30^{\circ}-36^{\circ} \mathrm{C} \\
15^{\circ}, 25^{\circ}, 29^{\circ}, 30^{\circ}, 36^{\circ}, 45^{\circ} \mathrm{C} \text { F }\end{array}$ & $\begin{array}{l}\text { Resolved both sides } \\
\text { Felt same both arms }\end{array}$ \\
\hline \multicolumn{2}{|c|}{$\begin{array}{l}\text { Deep Pain } \\
0.2 \mathrm{ml} \text {. of } 6 \% \text { sodium chloride was injected into identical } \\
\text { sites in both arms. Severe pain experienced on the left, } \\
\text { very slight ache on right. }\end{array}$} \\
\hline
\end{tabular}

\begin{tabular}{|c|c|}
\hline Right Leg & Left Leg \\
\hline $\begin{array}{l}\text { Position and Passive Movement } \\
\text { Toes } 20^{\circ} \text { direction correct }\end{array}$ & $5^{\circ}$ correct \\
\hline Vibration Diminished & 6 secs. longer \\
\hline Touch (wool) $8 / 10 \quad 8 / 10$ & $10 / 10$ \\
\hline $\begin{array}{l}\text { Pin-prick Gross impairment } \\
\text { up to mid thigh }\end{array}$ & Normal \\
\hline
\end{tabular}

Temperature and Deep Pain As for arm

Case No. 5 (No. 9639).-This man was wounded on August 19, 1944, by a fragment of a shell. He was never unconscious, and immediately noticed numbness and weakness of the left arm and numbness of the left face and tongue. He was examined at No. 6 M.N.S.U. within 12 hours of injury by Capt. P. L. M. Hartley, who found slight weakness of the left face. The left hand was profoundly weak, the arm less so, and it was noted that there was analgesia of the left hand. He was operated upon on August 21, 1944, by Capt. G. B. Northcroft. There was a parietal wound. The dural defect measured $1.5 \mathrm{~cm}$. $\times 1.0 \mathrm{~cm}$., and a track $2.5 \mathrm{~cm}$. in length led down, from which bone fragments were removed. His recovery was uneventful (Fig. 4). He was examined again in February, 1946, by Dr. M. J. McArdle. There was still impairment of position sense and 2-point discrimination. There was analgesia

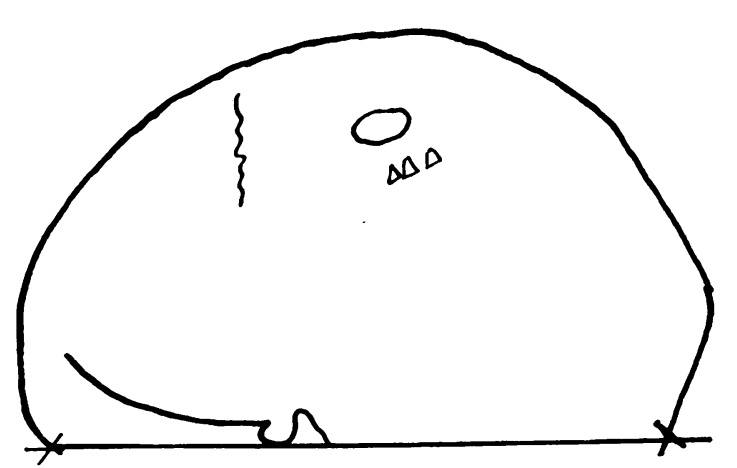

FIG. 4.-Tracing of lateral radiograph of skull showing site of wound in Case 5.

along the radial border of the left forearm with general hypoalgesia of the limb.

I examined him in September, 1950. He was well, working, and free from fits. The visual fields were full and the cranial nerves were normal. Power in the left arm was $80 \%$ of normal, except in the hand where there was only $20 \%$ power. The reflexes in the left arm were increased. Motor, sensory, and reflex findings in the legs were all normal. Sensory findings were :-

\begin{tabular}{|c|c|}
\hline Right Arm & Left Arm \\
\hline $\begin{array}{l}\text { Position and Passive Movement } \\
\text { Fingers } 5^{\circ} \text { direction correct } \\
\text { Wrist } \quad 5^{\circ} \text { direction correct }\end{array}$ & $\begin{array}{l}20^{\circ} \text { movement only } \\
10^{\circ} \text { direction correct }\end{array}$ \\
\hline Vibration 4 secs. longer & Feels less \\
\hline 2-point $\quad 0.4 \mathrm{~cm}$ & No threshold at $4 \mathrm{~cm}$. \\
\hline $\begin{array}{cr}\text { Touch (No. } 2 \text { nylon) } & 9 / 10 \\
\text { Wool } & 10 / 10 \\
\text { Finger dab } & 10 / 10\end{array}$ & $\begin{array}{ll}0 / 10 & \\
3 / 10 & 2 / 10 \\
8 / 10 & 8 / 10\end{array}$ \\
\hline Pin-prick Normal & $\begin{array}{l}\text { Gross impairment } \\
\text { with loss along } \\
\text { radial border (Fig. 5) }\end{array}$ \\
\hline $\begin{array}{l}\text { Temperature } \\
16^{\circ}-40^{\circ}: 35^{\circ}-39^{\circ} \mathrm{C} \text { Resolved } \\
16^{\circ}, 35^{\circ}, 39^{\circ}, 40^{\circ} \mathrm{C} \text { Same both }\end{array}$ & $\begin{array}{l}\text { Resolved } \\
\text { sides }\end{array}$ \\
\hline
\end{tabular}

\section{Deep Pain}

$0.2 \mathrm{ml}$. of $6 \%$ sodium chloride injected into identical sites in both arms with resulting severe pain on the right, but very slight vague aching on the left.

Case No. 6 (No. 11046).-This man was injured on February 27, 1945, when a shell fell near him. He recovered consciousness two minutes later and could see and hear normally, but both legs were numb and powerless. The left leg recovered in ten minutes but the right leg remained the same. He was seen at No. 1 M.N.S.U. some four hours later when paresis and loss of sensation in the right foot were noted. Major W. S. Keith operated next morning. There was 


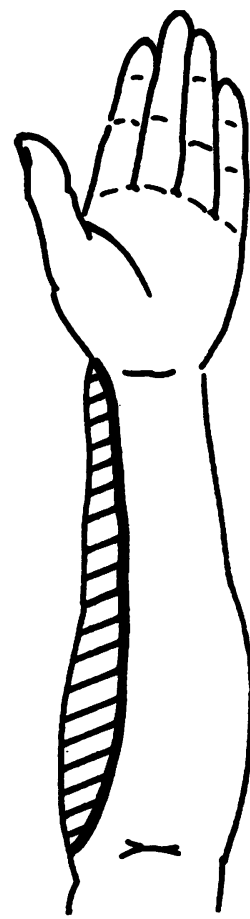

Fig. 5.-Area of loss of sensibility to pinprick in Case 5. a tiny penetration in the left frontal region with a small dural tear underlying. A superficial track ran backwards and on radiography a small foreign body was seen to lie superficially in the parietal lobe. He was examined by Dr. G. E. Smyth on March 19, 1945. There was a trace of right facial weakness, and in the right arm power was $90 \%$ normal with slight increase in the reflexes. In the right leg there was $90 \%$ power but tone and reflexes were increased, though the plantar response was flexor. On the sensory side position and vibration were impaired in the left foot; there was hypoalgesia of the foot but temperature was slowly but accurately resolved.

I examined the man five years later on August 25, 1950. The visual fields, cranial nerves, and arms were all normal. Power at the right knee was normal but was reduced to $60 \%$ in the right foot. The right knee and ankle jerks were increased but the plantar response was flexor. He had no fits. Sensory findings were :-

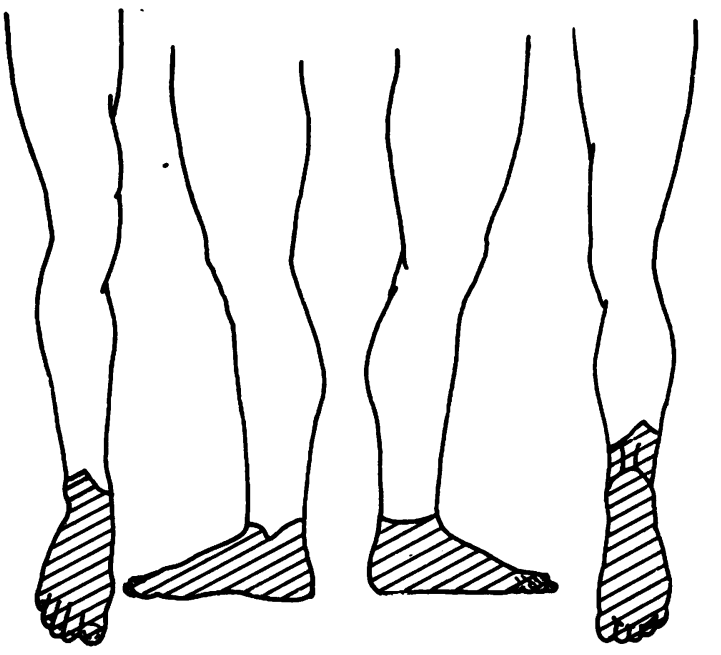

Fig. 6.-Area of gross impairment?of sensibility to pinprick in Case 6.

\begin{tabular}{|c|c|}
\hline Right Leg & Left Leg \\
\hline $\begin{array}{l}\text { Position and Passive Movement } \\
\text { Toes } \quad 15^{\circ} \text { movement only } \\
\\
30^{\circ} \text { direction correct }\end{array}$ & $5^{\circ}$ correct \\
\hline Diminished & Normal \\
\hline No threshold & $0.4 \mathrm{~cm}$. \\
\hline $\begin{array}{lll}\text { Touch } & \text { Foot } \\
\text { Wool } & 2 / 10 & 3 / 10 \\
\text { Finger dab } & 10 / 10\end{array}$ & $\begin{array}{l}10 / 10 \\
10 / 10\end{array}$ \\
\hline Gross impairment & Normal \\
\hline $\begin{array}{l}\text { Temperature } \\
21^{\circ}-41^{\circ}: 28^{\circ}-38^{\circ} \mathrm{C} \text { Resolved } \\
\text { in } 5 \text { secs. } \\
32^{\circ}-37^{\circ} \mathrm{C} \text { Resolved in } 5 \text { secs. } \\
28^{\circ} \mathrm{C} \text { Slightly colder on } 1 \\
32^{\circ}, 37^{\circ} \mathrm{C} \text { Slightly warmer on }\end{array}$ & $\begin{array}{l}\text { Resolved in } 1 \mathrm{sec} . \\
\text { Resolved in } 1 \mathrm{sec} . \\
\mathrm{ft} \\
\text { left }\end{array}$ \\
\hline
\end{tabular}

\section{Deep Pain}

Not tested because facilities for sterile injection were not available where this patient was tested.

Case No. 7. (No. 9713). - This man was wounded on August 18, 1944, receiving bullet wounds over the vertex of the skull and in the right axilla. The right arm had to be amputated some three days later because of gas gangrene. He did not lose consciousness at the time of wounding, but immediately became aware of loss of power in both legs. He was seen at No. 8 General Hospital on the following day, by which time the right leg had largely recovered. The left leg was very weak but reflexes were not increased. Both plantars were extensor. Position sense was lost in the left leg. The visual fields were full. He was operated on by Major J. M. Small on August 20. Bone fragments and lacerated brain were removed from a cherry-sized cavity near the vertex to the right of the sagittal sinus (Fig. 7). On

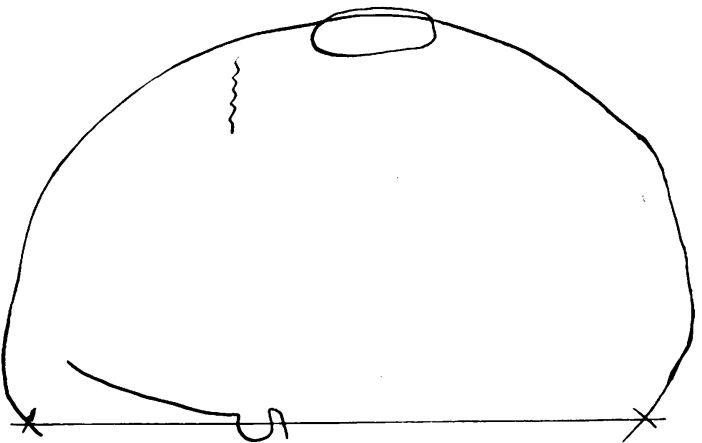

FIG. 7.-Tracing of lateral radiograph of skull showing site of wound in Case 7.

arrival at St. Hugh's Hospital, Oxford, on August 27, 1944 , the left leg was still very weak but flaccid, the plantar response was extensor and joint sense was grossly impaired. Pin-prick was reported as normal. 
He was examined by Dr. W. Ritchie Russell in February, 1945, when there was marked impairment of position and vibration sense in the left leg with very slight impairment of light touch. Threshold to pin-prick was raised but, when felt, the prick was associated with slight tingling.

I examined him on October 18, 1950. He had no fits and was happy at work as a time-keeper. The visual fields and cranial nerves were normal, as was the left arm and right leg. (The right arm had been amputated.) The left knee and ankle showed $60 \%$ power with slight increase in tone and reflexes and an extensor plantar response. Sensory findings were :-

\begin{tabular}{|c|c|}
\hline Right Leg & Left Leg \\
\hline $\begin{array}{l}\text { Position and Passive Movement } \\
\text { Toes } \quad 5^{\circ} \text { correct }\end{array}$ & $\begin{array}{c}5^{\circ} \text { movement only } \\
30^{\circ} \text { direction correct }\end{array}$ \\
\hline Vibration 9 secs. longer & Diminished \\
\hline 2-point Foot $4 \mathrm{~cm}$ & No threshold \\
\hline Touch (No. 1 nylon) 10/10 & $10 / 10$ \\
\hline Pin-prick Normal & $\begin{array}{l}\text { Gross impairment to } \\
\text { mid-thigh }\end{array}$ \\
\hline
\end{tabular}

Temperature

$20^{\circ}-40^{\circ}: 32^{\circ}-38^{\circ} \mathrm{C}$ Resolved Resolved $20^{\circ}, 32^{\circ}, 38^{\circ}, 40^{\circ} \mathrm{C}$ Same both sides

\section{Deep Pain}

Not tested as facilities for sterile injection were not available where this patient was seen.

Case No. 8 (No. 11795). - This man sustained a depressed fracture in the left parietal region at Arnhem on September 24, 1944. He was unconscious only a few minutes. Records of his subsequent progress are scanty as he was taken prisoner, but he had considerable dysphasia. The fracture was elevated on November 21 . In February, 1945, he started with motor Jacksonian attacks involving the right hand but these ceased in 1948. He still has attacks in which he gets alternate freezing and burning sensations in the right index, middle, and ring fingers which rapidly spread up the arm and involve the right second and third divisions of the trigeminal nerve. The episodes last about a minute but there is no loss of consciousness. He was free from these episodes when examined.

I examined him in June, 1950. There was no field defect, and the cranial nerves, reflexes, and motor side were all normal. Sensory findings were :-

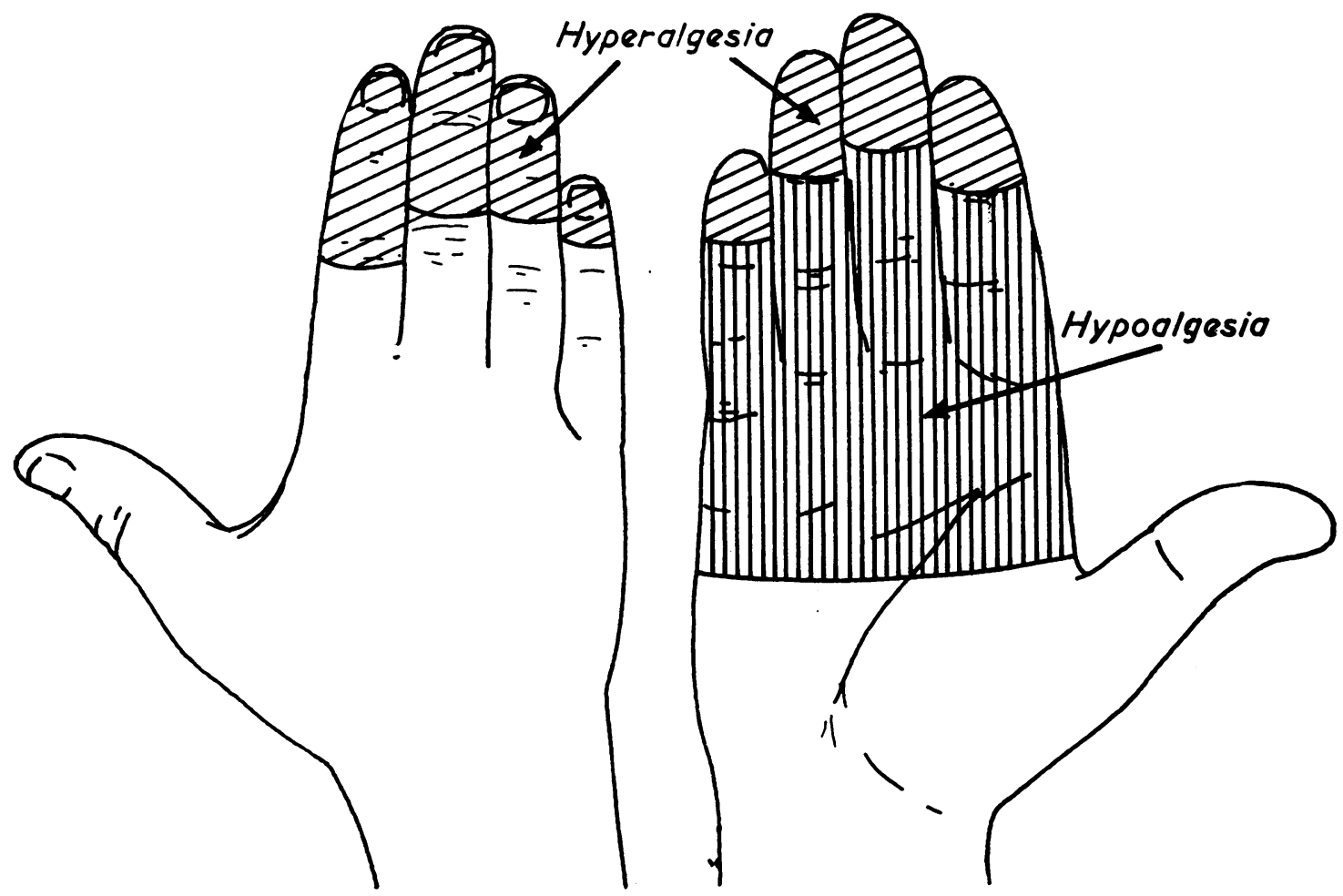

FIG. 8.-Areas of disturbance of sensibility to pin-prick in Case 8. 


\begin{tabular}{|c|c|}
\hline Right Arm & Left Arm \\
\hline $\begin{array}{l}\text { Position and Passive Movement } \\
\text { Fingers } 20^{\circ} \text { correct }\end{array}$ & $5^{\circ}$ correct \\
\hline Vibration . Diminished & 8 secs. longer \\
\hline 2-point Fingers $0.4 \mathrm{~cm}$. & $0.4 \mathrm{~cm}$ \\
\hline $\begin{array}{l}\text { Touch Fingers } \\
\text { No. } 2 \text { nylon } 5 / 10 \quad 6 / 10\end{array}$ & $10 / 10$ \\
\hline See Fig. 8 & Normal \\
\hline
\end{tabular}

Deep Pain

$0.2 \mathrm{ml}$. of $6 \%$ sodium chloride injected into identical sites in small muscles of both hands with very slight pain on the right and severe pain on the left.

\begin{tabular}{l}
\hline Temperature \\
$30^{\circ}-36^{\circ}: 34^{\circ}-38^{\circ} \mathrm{C}$ Not \\
resolved \\
$43^{\circ}, 41^{\circ}, 39^{\circ} \mathrm{C}$ Hotter and \\
painful on right \\
$37^{\circ} \mathrm{C}$ Hotter on right thumb, \\
index and middle fingers \\
only \\
$34^{\circ} \mathrm{C}$ Same both sides
\end{tabular}

Sensory findings in the legs were all normal.

Case No. 9. (No. 8800).-This man was wounded by a shell splinter in the right parietal region on June 26 , 1944. He was unconscious for not more than two minutes. He was examined the same day by Capt. P. L. M. Hartley at No. 6 M.N.S.U. The visual fields, cranial nerves, and legs were normal but there was a flaccid monoplegia of the left arm with loss of all forms of sensation. He was operated upon by Major J. M. Small 36 hours after injury. The skull was fractured, and the dura was torn with indriven fragments of bone and metal. These were removed but the depth of the track was not stated. He was last examined jointly by Dr. W. Ritchie Russell and Dr. M. J. McArdle in November, 1945. He was then found to have severe impairment of position sense, 2-point, and touch in the left arm. In addition there was a gross raising of the threshold to pin-prick in the left hand.

I examined him in August, 1950. He was on full-time work and had no fits. The visual fields were full but there was a trace of left facial weakness. There was increase of tone and reflexes in the left arm, with power at $60 \%$ of normal. The legs were normal. Sensory findings were :-

\begin{tabular}{|c|c|}
\hline Right Arm & Left Arm \\
\hline 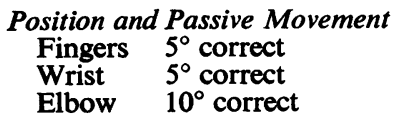 & $\begin{array}{l}30^{\circ} \text { movement only } \\
20^{\circ} \text { direction correct } \\
10^{\circ} \text { direction correct }\end{array}$ \\
\hline Vibration 9 secs. longer & Diminished \\
\hline
\end{tabular}

\begin{tabular}{|c|c|c|}
\hline \multicolumn{2}{|c|}{ Right Arm } & Left Arm \\
\hline \multicolumn{2}{|c|}{$0.3 \mathrm{~cm}$} & No threshold at $6 \mathrm{~cm}$. \\
\hline $\begin{array}{l}\text { Touch Woo } \\
\text { Finger dab }\end{array}$ & $\begin{array}{l}10 / 10 \\
10 / 10\end{array}$ & $\begin{array}{l}1 / 10 \\
7 / 10\end{array}$ \\
\hline Pin-prick & rmal & $\begin{array}{l}\text { Gross impairment } \\
\text { with } 1 \text { sec. delay } \\
\text { up to wrist }\end{array}$ \\
\hline
\end{tabular}

Temperature

$23^{\circ}-41^{\circ}: 30^{\circ}-35^{\circ} \mathrm{C}$ Resolved Resolved

$34^{\circ}-39^{\circ}: 39^{\circ}-43^{\circ} \mathrm{C}$ Resolved

$23^{\circ}, 30^{\circ}, 35^{\circ}, 41^{\circ} \mathrm{C}$ Normal

Not resolved

Delay of 4 secs.

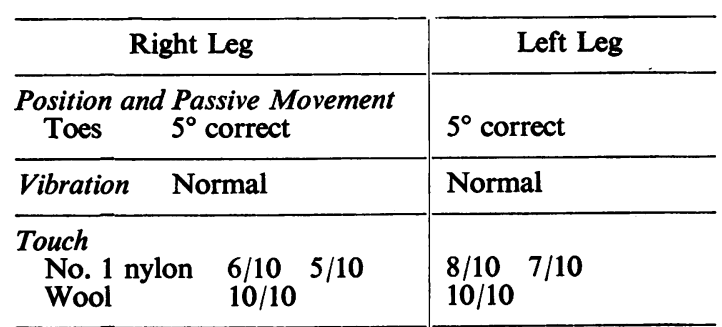

\begin{tabular}{ll|l}
\hline 2-point & $2.5 \mathrm{~cm}$. & No threshold at $7 \mathrm{~cm}$. \\
\hline Pin-prick & Normal & $\begin{array}{l}\text { Feels same but delay } \\
\text { of } 1 \text { sec. }\end{array}$
\end{tabular}

Case No. 10.-This man was wounded in 1916 in the left parietal region.

The period of post-traumatic amnesia is uncertain but was probably less than 48 hours. He was left with weakness of the right hand and some difficulty in writing. His speech was unaffected. Initially he had some fits but he had been free for ten years.

I examined him in December, 1950. There was no verbal dysphasia but there was some dysgraphia. The visual fields were full and cranial nerves were normal. Power in the right hand was $80 \%$ normal and the reflexes were slightly increased. The legs were normal.

Sensory findings were :-

FIG. 9.-Areas of impairment of sensibility to pin-prick in Case 10.

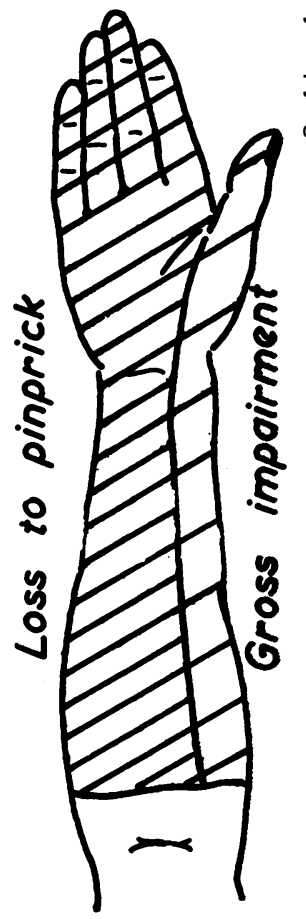

Fig. 9 


\begin{tabular}{|c|c|c|}
\hline \multicolumn{2}{|c|}{ Right Arm } & Left Arm \\
\hline $\begin{array}{c}\text { Position al } \\
\text { Fingers } \\
\text { Wrist } \\
\text { Elbow }\end{array}$ & $\begin{array}{l}\text { d Passive Movement } \\
90^{\circ} \text { failed } \\
20^{\circ} \text { movement only } \\
10^{\circ} \text { direction correct }\end{array}$ & $\begin{array}{l}5^{\circ} \text { correct } \\
5^{\circ} \text { correct } \\
5^{\circ} \text { correct }\end{array}$ \\
\hline $\begin{array}{c}\text { Vibration } \\
\text { Wrist } \\
\text { Elbow }\end{array}$ & $\begin{array}{l}\text { Lost } \\
\text { Diminished }\end{array}$ & $\begin{array}{l}\text { Normal } \\
\text { Normal }\end{array}$ \\
\hline 2-point & No threshold at $5 \mathrm{~cm}$. & $0.4 \mathrm{~cm}$ \\
\hline
\end{tabular}

\begin{tabular}{l|l}
\hline $\begin{array}{c}\text { Touch } \\
\text { No. 2. nylon } 0 / 10 \text { in forearm } \\
\text { Wool } \quad 0 / 10 \text { in forearm }\end{array}$ & $10 / 10$ \\
\hline Pin-prick See Fig. 9 & Normal \\
\hline $\begin{array}{c}\text { Temperature } \\
28^{\circ}-42^{\circ}: \\
\text { resolved }\end{array}$ & Resolved \\
\hline
\end{tabular}

Deep Pain

$0.2 \mathrm{ml}$. of $6 \%$ sodium chloride injected into right hand with no pain.

Case No. 11. (No. 10910). - This patient sustained a penetrating wound of the right parietal region in February, 1945. He did not lose consciousness. He was

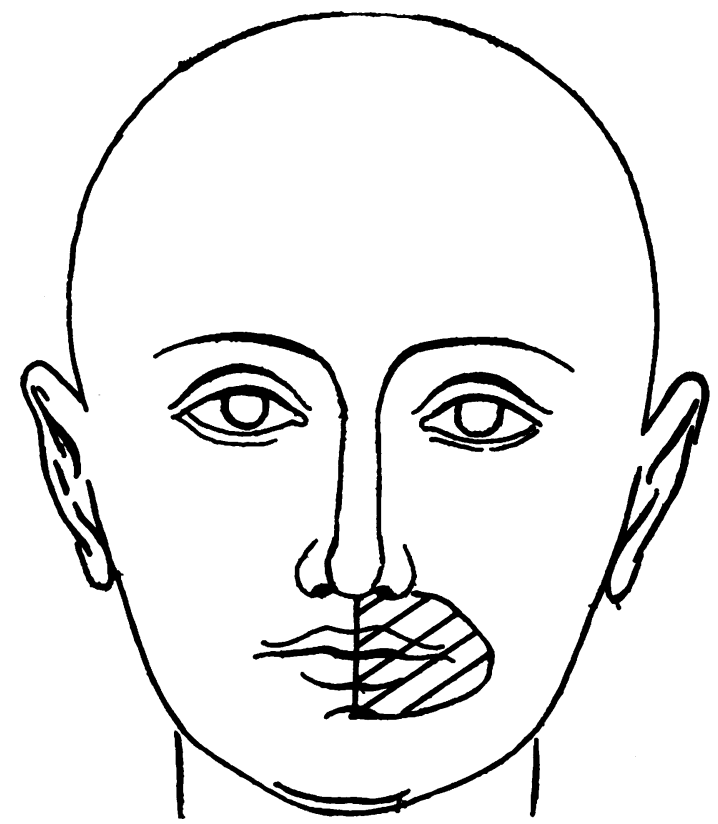

FIG. 10.-Area of gross impairment of sensibility to pinprick on face in Case 11 .

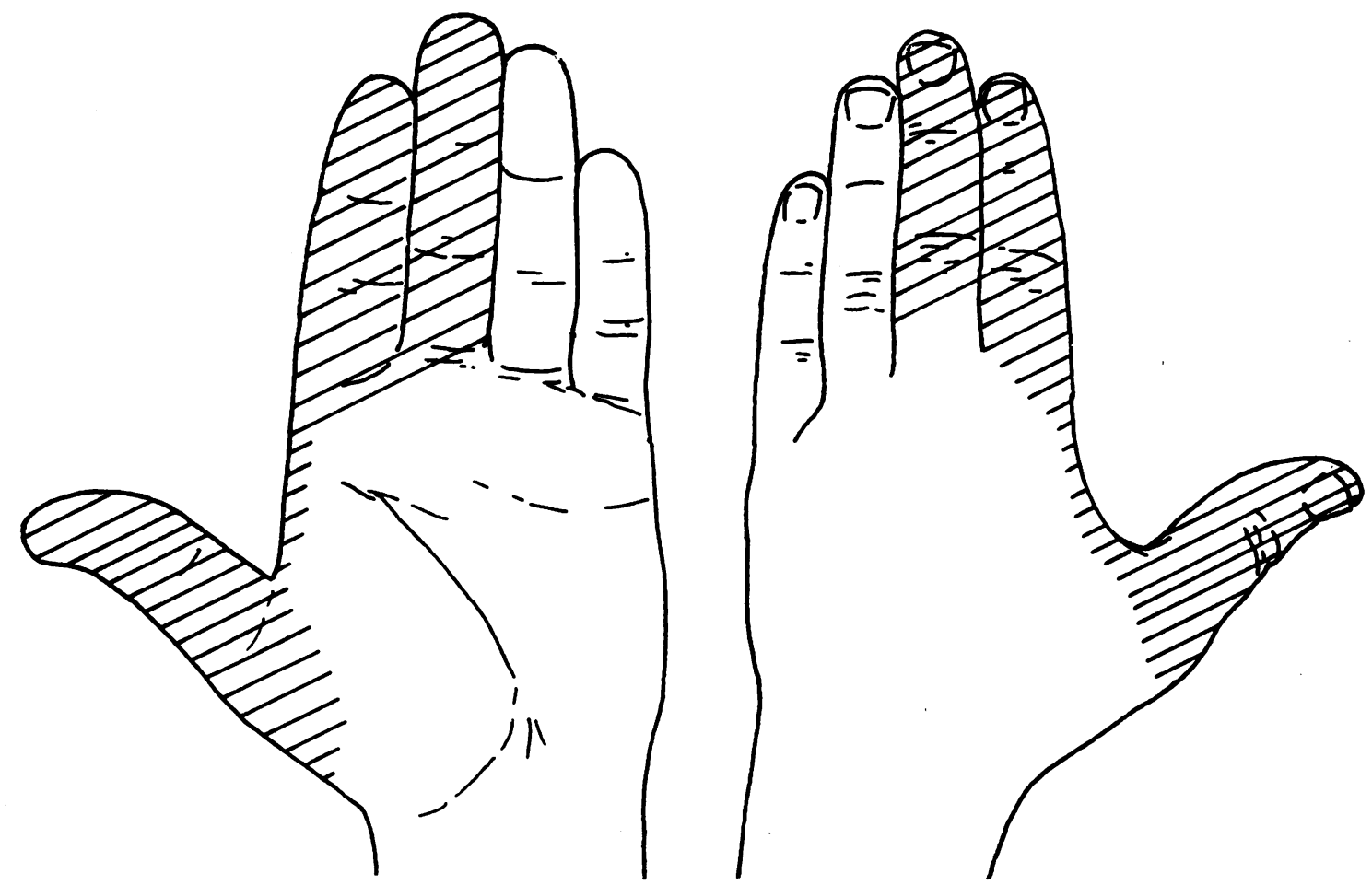

Fig. 11.-Area of gross impairment of sensibility to pin-prick in left hand in Case 11. 
examined at No. 1. M.N.S.U. eight hours later by Major C. C. Grey when he was found to have weakness of the left face and hand with impairment of position sense, 2-point; touch, and pin-prick in the left hand also. He was operated upon 26 hours after injury by Major W. S. Keith. A $\frac{3}{4}$ in. tear in the dura was found and a small amount of necrotic brain lay below. He was finally examined in April, 1945, by Dr. G. E. Smyth when there was a trace of left facial weakness and an area of hypoalgesia over the left upper and lower lip and some impairment of pain sensation in the left hand.

I examined him in February, 1951. He was at work as a storekeeper and had no fits. There were no motor disturbances and the visual fields were full. The cranial nerves were normal except for the trigeminal in which territory there was hypoalgesia. The sensory findings were as follows :-

\begin{tabular}{|c|c|}
\hline Right Arm & Left Arm \\
\hline $\begin{array}{l}\text { Position and Passive Movement } \\
\text { Fingers } 5^{\circ} \text { correct }\end{array}$ & $5^{\circ}$ correct \\
\hline Vibration 7 secs. longer & Diminished \\
\hline 2-point $\quad 0.5 \mathrm{~cm}$ & $0.5 \mathrm{~cm}$ \\
\hline Touch (No. 2 nylon) $10 / 10$ & $10 / 10$ \\
\hline Pin-prick Normal & See Figs. 10 and 11 \\
\hline $\begin{array}{l}\text { Temperature } \\
32^{\circ}-36^{\circ}: 36^{\circ}-40^{\circ} \mathrm{C} \text { Resolved } \\
32^{\circ}, 36^{\circ}, 40^{\circ} \mathrm{C} \text { Same both sides }\end{array}$ & Resolved \\
\hline Deep Pain Not tested. & \\
\hline
\end{tabular}

Series B.-This group consisted of patients with cortical wounds with hyperpathia.

Case No. 12. (No. 11635).-This patient sustained a through and through wound from a rifle bullet, from the right parietal to the left occipital region, on April 20, 1945. He had post-traumatic amnesia lasting for 15 minutes. He was examined at No. 6 M.N.S.U. by Capt. A. C. Watt the next day. He appeared to have light perception only. There was a slight weakness of the left face with marked paralysis of the left arm. The leg was only slightly weak. Reflexes and tone were increased on the left but the plantar response was flexor. All modalities of sensation appeared to be depressed on the left. Operation was performed the same day. Both wounds were small as were the tracks joining them. These were sucked clear of clot and after irrigation with penicillin were closed. Two days later further clot had to be removed from the right parietal wound. He was last examined in December, 1945, when impaired sensation on the left side was noted.

I examined him on August 8, 1950. The visual fields were full, but there was defective localization in the left homonymous field. Power in the left shoulder and elbow was $80 \%$, but in the hand there was only slight movement. Power in the left leg was about $60 \%$. There was increase of tone and reflexes on the left side and the left plantar response was extensor. He had no fits. Sensory findings were :-

\begin{tabular}{|c|c|}
\hline Right Arm & Left Arm \\
\hline $\begin{array}{ll}\text { Position and Passive Movement } \\
\text { Fingers } & 5^{\circ} \text { correct } \\
\text { Wrist } & 5^{\circ} \text { correct } \\
\text { Elbow } & 5^{\circ} \text { correct }\end{array}$ & $\begin{array}{l}50^{\circ} \text { movement only } \\
10^{\circ} \text { movement only } \\
10^{\circ} \text { direction correct }\end{array}$ \\
\hline 8 secs. longer & Diminished \\
\hline $0.4 \mathrm{~cm}$ & No threshold \\
\hline $\begin{array}{l}\text { Touch Fingers } \\
\text { Wool } 10 / 10 \\
\text { No. } 2 \text { nylon } 8 / 10 \quad 7 / 10 \\
\text { Arms Wool } 10 / 10\end{array}$ & $\begin{array}{l}8 / 10 \\
7 / 10 \\
10 / 10\end{array}$ \\
\hline
\end{tabular}

Pin-prick Normal on right; on left pain is much more severe, spreads over an area, and lasts longer ; likewise on trunk and second and third divisions of trigeminal.

Temperature
$23^{\circ}-39^{\circ}: 34^{\circ}-38^{\circ} \mathrm{C}$ Resolved
$39^{\circ}, 38^{\circ} \mathrm{C}$ Warmer on right
$37^{\circ} \mathrm{C}$ Same both sides
$36^{\circ}, 34^{\circ}, 23^{\circ} \mathrm{C}$ Colder on right

\begin{tabular}{|c|c|}
\hline Right Leg & Left Leg \\
\hline $\begin{array}{ll}\text { Position and Passive Movement } \\
\text { Toes } & 5^{\circ} \text { correct } \\
\text { Ankle } & 5^{\circ} \text { correct } \\
\text { Knee } & 5^{\circ} \text { correct } \\
\text { Hip } & 5^{\circ} \text { correct }\end{array}$ & $\begin{array}{l}\text { Lost } \\
45^{\circ} \text { movement only } \\
20^{\circ} \text { movement only } \\
10^{\circ} \text { direction correct }\end{array}$ \\
\hline Vibration 3 secs. longer & Diminished \\
\hline $\begin{array}{ll}\text { Touch Foot } & \\
\text { Wool } & 10 / 10 \\
\text { No. } 2 \text { nylon } & 10 / 10\end{array}$ & $\begin{array}{l}9 / 10 \\
5 / 10\end{array}$ \\
\hline
\end{tabular}

Pin-prick As for arm

The left half of the scrotum was not hyperalgesic to pin-prick, nor was the ophthalmic division of the trigeminal nerve on the left.

Case No. 13. (No. 18403).- - This man sustained a wound in the left parietal region in July, 1944, by a bullet from a Sten gun. He was unconscious for less than five minutes and on recovery found weakness and numbness of the right arm and leg and some difficulty with his speech. There was no visual defect. The speech and leg recovered rapidly but he had persistent weakness and sensory disturbance in the right arm. In December, 1944, he developed grand mal epileptic attacks with a frequency of one every six months.

I examined him in September, 1950. He was at work regularly as an electrical welder. His last fit was in June, 1950 , on the occasion of a dental extraction, and before that he had been free from fits for 18 months. He had a momentary loss of consciousness a month before examination. The visual fields and cranial nerves were 
normal, as also were the legs. The right arm showed $80 \%$ normal power, the hand $60 \%$, and the arm reflexes were increased.

Sensory findings were :-

\begin{tabular}{|c|c|}
\hline Right Arm & Left Arm \\
\hline $\begin{array}{l}\text { Position and Passive Movement } \\
\text { Thumb and index } 5^{\circ} \text { correct } \\
345 \text { digits } 30^{\circ} \text { direction correct }\end{array}$ & $\begin{array}{l}5^{\circ} \text { correct } \\
5^{\circ} \text { correct }\end{array}$ \\
\hline Vibration Normal & Normal \\
\hline $\begin{array}{l}\text { 2-point } \\
\text { Thumb and index } 0.5 \mathrm{~cm} \text {. } \\
345 \text { digits No threshold } \\
\text { at } 4 \mathrm{~cm} \text {. }\end{array}$ & $\begin{array}{l}0.5 \mathrm{~cm} \\
0.5 \mathrm{~cm}\end{array}$ \\
\hline $\begin{array}{l}\text { Touch (No. } 2 \text { nylon) } \\
\text { Thumb and index } 10 / 10 \\
345 \text { digits } 2 / 10 \quad 1 / 10\end{array}$ & $\begin{array}{l}10 / 10 \\
10 / 10\end{array}$ \\
\hline $\begin{array}{l}\text { Pin-prick } \\
\text { Thumb and index normal } \\
345 \text { digits Much more pain- } \\
\text { ful than right thumb and } \\
\text { index or than left hand }\end{array}$ & $\begin{array}{l}\text { Normal } \\
\text { Normal }\end{array}$ \\
\hline $\begin{array}{l}\text { Temperature } \\
20^{\circ}-36^{\circ}: 28^{\circ}-35^{\circ} \mathrm{C} \text { Resolved } \\
20^{\circ} \mathrm{C} \text { Colder on right } 345 \mathrm{dig} \\
28^{\circ}, 35^{\circ} \mathrm{C} \text { Same both sides }\end{array}$ & $\begin{array}{l}\text { Resolved } \\
\text { gits than on left }\end{array}$ \\
\hline
\end{tabular}

Series C.-This comprised patients with cortical wounds with impairment of temperature sense but in whom the sense of pain was preserved.

Case No. 14. (No. 8715).- - This man was wounded on June 20, 1944, by shell splinters. He was thrown on the floor by the force of the explosion but did not lose consciousness. He was examined at St. Hugh's Hospital, Oxford, on June 22, 1944, by Dr. M. J. McArdle. He was somewhat drowsy, but was quite rational and well orientated. There was an attention defect in the left half visual field and a left facial weakness. The left arm showed moderate decrease in power with depressed reflexes; the left leg was only slightly weak. Both plantars were extensor. On the sensory side there was noted to be postural impairment in the left fingers and toes. He was operated upon on June 23 . There were three wounds in the right parietal region, two of which were superficial. Below the third wound was a small depressed fracture which was included in a burr-hole. Beneath this was a dural tear measuring $0.3 \mathrm{~cm} . \times 0.2$ $\mathrm{cm}$., from which led a small track $1 \mathrm{~cm}$. in depth, where a bone chip was lodged. This was removed. The last recorded examination was made by Dr. M. J. McArdle on July 3, 1944. He found severe disturbance of position and vibration sense in the left arm with slighter affection of the leg. Light touch and temperature sense were likewise severely diminished in the left arm. Superficial pain and pressure pain were, however, on several testings found to be unaffected.

I examined this man six years later, on October 17 ,
1950. He had kept well, was free from symptoms, hard at work as a farmer, and had had no fits since his discharge from hospital, where he had two Jacksonian attacks involving the left face and arm. General power in the left arm was good, apart from finger flexion which was still only $40 \%$. Reflexes were equal, plantars flexor, visual fields were full and the cranial nerves intact. The legs were normal.

Sensory findings were :-

\begin{tabular}{|c|c|}
\hline Right Arm & Left Arm \\
\hline $\begin{array}{l}\text { Position and Passive Movement } \\
\text { Fingers } 10^{\circ} \text { correct }\end{array}$ & $10^{\circ}$ correct \\
\hline Vibration Normal & Diminished \\
\hline 2-point & No threshold at $4 \mathrm{~cm}$. \\
\hline $\begin{array}{cc}\text { Touch Wool } & 10 / 10 \\
\text { Finger dab } & 10 / 10\end{array}$ & $\begin{array}{l}4 / 105 / 10 \\
10 / 10\end{array}$ \\
\hline Pin-prick Normal & Normal \\
\hline $\begin{array}{l}\text { Temperature } \\
20^{\circ}-43^{\circ} \mathrm{C} \text { Resolved } \\
43^{\circ} \mathrm{C} \text { After long delay felt sl }\end{array}$ & $\begin{array}{l}\text { Not resolved } \\
\text { ghtly warm }\end{array}$ \\
\hline \multicolumn{2}{|c|}{$\begin{array}{l}\text { Deep Pain } \\
0.2 \mathrm{ml} \text {. of } 6 \% \text { sodium chloride was injected into } \\
\text { identical sites in the muscles of both arms with } \\
\text { production of exactly the same degree of pain. }\end{array}$} \\
\hline
\end{tabular}

Case No. 15. (No. 9469). - This man sustained a mortar wound of the right posterior parietal region in August, 1944. His post-traumatic amnesia did not develop until half an hour after injury during which time he noted that his left arm and leg felt numb. The amnesia lasted from 12 to 24 hours. He was operated upon by Col. C. A. Calvert some 48 hours later. There was a small dural tear with a track $4 \mathrm{~cm}$. deep. In March, 1945, he had a fit beginning in the left arm, since when he had eight or nine in all, the last in June, 1950.

I examined him in August, 1950. He was at work as a manager of a building firm. The visual fields and cranial nerves were normal. There was no motor weakness, but reflexes in the left leg were slightly increased. Plantar responses were flexor.

Sensory findings were :-

\begin{tabular}{|c|c|}
\hline Right Arm & Left Arm \\
\hline $\begin{array}{l}\text { Position and Passive Movement } \\
\text { Fingers } 5^{\circ} \text { correct }\end{array}$ & $5^{\circ}$ correct \\
\hline Vibration Normal & Normal \\
\hline Touch (No. 2 nylon) Normal & Normal \\
\hline $0.3 \mathrm{~cm}$ & $0.3 \mathrm{~cm}$. \\
\hline Pin-prick & Normal \\
\hline
\end{tabular}




\begin{tabular}{|c|c|}
\hline Right Leg & Left Leg \\
\hline $\begin{array}{l}\text { Position and Passive Movement } \\
\text { Toes } 55^{\circ} \text { correct } \\
\text { Ankle } \quad 5^{\circ} \text { correct }\end{array}$ & $\begin{array}{l}5^{\circ} \text { movement only } \\
10^{\circ} \text { direction correct }\end{array}$ \\
\hline 3 secs. longer & $\begin{array}{l}\text { No subjective impair- } \\
\text { ment }\end{array}$ \\
\hline 2-point & $2 \mathrm{~cm}$ \\
\hline $\begin{array}{ll}\text { Touch } \\
\text { No. } 1 \text { nylon } & 6 / 10 \\
\text { No. } 2 \text { nylon } & 10 / 10\end{array}$ & $\begin{array}{l}5 / 10 \\
10 / 10\end{array}$ \\
\hline Pin-prick & Normal \\
\hline
\end{tabular}

\begin{tabular}{|c|c|}
\hline $\begin{array}{l}\text { Temperature } \\
36^{\circ}-40^{\circ} \mathrm{C} \text { Resolved }\end{array}$ & Resolved \\
\hline Right Leg & Left Leg \\
\hline $\begin{array}{l}\text { Position and Passive Movement } \\
\text { Toes } \quad 5^{\circ} \text { correct }\end{array}$ & $30^{\circ}$ correct \\
\hline Vibration & Normal \\
\hline $2.5 \mathrm{~cm}$ & $7.5 \mathrm{~cm}$. \\
\hline $\begin{array}{ll}\text { Touch } & \\
\quad \text { No. } 2 \text { nylon } & 10 / 10 \\
\text { Wool } & 10 / 10\end{array}$ & $\begin{array}{l}9 / 10 \\
10 / 10\end{array}$ \\
\hline Pin-prick & Normal \\
\hline Deep Pain Not tested & \\
\hline
\end{tabular}

\section{Temperature}

$23^{\circ}-43^{\circ}, 23^{\circ}-36^{\circ}, 25^{\circ}-31^{\circ}, 39^{\circ}-44^{\circ} \mathrm{C}$ Resolved both legs $23^{\circ}, 31^{\circ} \mathrm{C}$ Feels colder on the left

$35^{\circ} \mathrm{C}$ Feels same both sides

$39^{\circ}, 43^{\circ} \mathrm{C}$ Feels warmer on the left

Appreciation of temperature takes 2 secs. longer on left.

\section{Deep Pain}

Not tested owing to lack of facilities for sterile injection where this patient was examined.

Series D.-This consisted of patients with extensive wounds with loss of discriminative sensibility, but in whom the sense of pain was preserved.

Case No. 16. (No. 8911).-This officer was wounded in the right parietal region on June 10,1944 , by a shell splinter. He was unconscious for three days. He was examined by Capt. R. Jepson on June 11, when there was found a left homonymous hemianopia and a left hemiplegia with an extensor plantar response. Capt. R. Jepson operated the same day. There was a dural defect measuring 1 in. $\times \frac{1}{2}$ in. and a moderate-sized cavity with indriven bone fragments. He was finally examined in September, 1945. He had a defect in the left upper quadrant of the visual fields and a mild left hemiplegia. Position sense was impaired on the left side but pin-prick was normal.

I examined him in August, 1950. There was no demonstrable field defect and the legs were normal. There was a fair degree of weakness in the left arm. He had no fits. Sensory findings were :-

\begin{tabular}{|c|c|}
\hline Right Arm & Left Arm \\
\hline $\begin{array}{c}\text { Position and Passive Movement } \\
\text { Fingers } 5^{\circ} \text { correct } \\
\text { Wrist } 10^{\circ} \text { correct }\end{array}$ & $\begin{array}{l}90^{\circ} \text { movement only } \\
20^{\circ} \text { direction correct }\end{array}$ \\
\hline Vibration & $\begin{array}{l}\text { Slight subjective } \\
\text { diminution }\end{array}$ \\
\hline $0.3 \mathrm{~cm}$ & No threshold \\
\hline Touch (No. 2 nylon) $10 / 10$ & $10 / 10$ \\
\hline Pin-prick Normal & Normal \\
\hline
\end{tabular}

Case No. 17. (No. 12249).-This patient sustained a through and through wound with entry in the left occipital region near the midline and exit in the parietal region near the midline on the same side on April 20, 1945. He was unconscious for a few minutes only. He was examined the following day at No. 4 M.N.S.U. when he was found to have a right hemiparesis with 0 weakness and increased tone in the left leg also. Position sense was lost on the right. He was operated upon the same day when there was a gutter $5 \mathrm{~cm}$. in depth between entry and exit wounds.

I examined him in March, 1950. The visual fields were full, but he had a fairly dense hemiplegia on the right side. The right plantar was extensor, the lefte flexor. He had two fits in 1945 but none since. Sensory findings were :-

\begin{tabular}{l|l}
\hline \multicolumn{1}{|c|}{ Right Arm } & \multicolumn{1}{|c}{ Left Arm } \\
\hline $\begin{array}{l}\text { Position and Passive Movement } \\
\text { Fingers } 90^{\circ} \text { failed }\end{array}$ & $5^{\circ}$ correct \\
\hline Vibration Diminished & Normal \\
\hline \begin{tabular}{l} 
Touch (wool) $\quad 10 / 10$ \\
\hline Pin-prick Normal
\end{tabular} & $10 / 10$ \\
\hline
\end{tabular}

\begin{tabular}{|c|c|}
\hline Right Leg & Left Leg \\
\hline $\begin{array}{l}\text { Position and Passive Movement } \\
\text { Toes } \quad 90^{\circ} \text { failed }\end{array}$ & $5^{\circ}$ correct \\
\hline Diminished & Normal \\
\hline Touch (wool) & $10 / 10$ \\
\hline Pin-prick Normal & Normal \\
\hline
\end{tabular}

Deep Pain

$0.2 \mathrm{ml}$. of $6 \%$ sodium chloride injected into identical sites in arms and legs. There was no difference in the degree of pain experienced. 
Case No. 18: Cortical Neoplasm with Pain Loss.A married woman of 43 years was admitted to the Manchester Royal Infirmary, under the care of Dr. Fergus R. Ferguson, on January 21,1946 . Her history was that six months previously she had begun with right-sided Jacksonian attacks with unconsciousness lasting up to 20 minutes. In all she had had five of these attacks. On December 12, she began to lose the power in her right arm and leg, and she also developed difficulty in speaking.

On admission she was markedly dysphasic. Her mental condition was, however, excellent, as was shown by her agitation when her husband made errors in giving her history for her and the signs she made in order to correct him. Examination showed a spastic weakness of the right arm and leg with involvement of the right face. The visual fields and cranial nerves were otherwise normal. On the sensory side there was marked astereognosis and loss of position sense. There was a marked hypoalgesia to pin-prick over the whole of the right side extending to within 1 or $2 \mathrm{~cm}$. of the midline. On February 2, 1946, she had a further fit, following which she rapidly passed into coma and died. At necropsy there was found in the left fronto-parietal region a tumour $6 \mathrm{~cm}$. in diameter which proved to be an isomorphic glioblastoma. The growth was mainly cortical and the thalamus was definitely not invaded.

\section{Discussion}

The first concern in presenting material of this kind must be to anticipate a series of objections which, if sustained, might render any succeeding deductions invalid. The cases in this report have been chosen especially with a view to avoiding these pitfalls. Thus, unlike neoplasms, traumatic material gives little uncertainty as to the extent of the lesion, for in two-thirds of these cases the depth of the wound at the end of an operation is given. Of the remainder, Case 8 has only a scanty operative report, but as he had only a depressed fracture the underlying injury can only have been superficial. In Cases 9 and 10, notes about the depth of the wound are also lacking, but as the resultant deficit was monoplegic in distribution the wound cannot have been deep. Of the remaining cases no wound was deeper than $3 \mathrm{~cm}$.- except in Case 15 where the track was $4 \mathrm{~cm}$.

Further evidence as to the superficial nature of the wound is obtained from a consideration of the resultant neurological deficit. Thus in Series A the residual deficit was monoplegic in distribution in nine instances, while in the two other cases (Cases 2 and 4) both arm and leg were involved.

It is worth noting that in Cases 8,9 , and 10 , where the operative details are scanty, the neurological deficit was only monoplegic in distribution. There can, therefore, be no hesitation in affirming that these wounds did not involve the thalamus but were cortical in site and effect.
The second fallacy which must be considered is the occurrence of oedema, pressure, and vascular disturbances around the site of the lesion. Russell (1945) has pointed out that there are frequently marked sensory changes in brain wounds which recover rapidly as the effects of shock pass off. In the present series there can be no possibility of the findings described being transient, as the shortest period elapsing between wounding and the last examination was two years. Moreover, the findings in the final examination were substantially the same as the last previously recorded examination, indicating that the condition had achieved stability.

The possibility of remote cerebral damage due to concussion has been avoided by omitting cases with a long post-traumatic amnesia. Thus in Series A, B, and C, 12 cases were unconscious less than five minutes, one less than 15 minutes, and the remaining two less than 48 hours.

A further source of error stressed by Holmes (1927b) is the altered sensory findings which may follow epileptic attacks. In the present series nine of the 15 cases had never had a fit. Of the remainder, Case 10 had been free for ten years, Case 14 for six, and Case 8 for two years, except for momentary sensory disturbance without loss of consciousness. Cases 2 and 13 had no attacks in the three months before examination and Case 15 had been free for two months. The sensory findings were not, therefore, due to epileptic disturbances. Also the sensory findings were constant and unvarying, a feature most unlike a post-ictal phenomenon.

The possibility that the areas of sensory loss are hysterical might be raised, but great care has been taken that no such suspicion could be directed against the cases in the present series. The personality of all the patients was good, and at no stage had they shown any evidence of psychiatric disturbance. Since discharge from hospital they had good work records. Their attitude to examination was cooperative and critical. Further objective evidence as to the absence of hysteria from these cases is seen in the occurrence of dissociated sensory loss. For example, in Case 2, though pin-prick was impaired on the left side, temperature sense was normal in the arm and delayed though accurate in the leg. In Cases 3 and 5 sensory charts made without any prompting or suggestion were exact replicas of charts made five and four years previously. Case 9 had a raised threshold to pinprick, confined to the left hand in 1945, a finding confirmed in 1950. Case 10 was analgesic over the right fingers and palm but only hypoalgesic over the thumb. Moreover, these sensory observations have been repeatedly confirmed in the present 
study, and every effort was made to shake the patient's constancy in asserting that he could not feel pain or pin-prick in an area. There can, therefore, be no doubt that the sensory findings recorded here were not hysterical in origin.

A final difficulty to be avoided is that referred to by Head (1920) when he wrote :

"A second difficulty arises from the fact that the first effect produced by pricking with a sharp needle is recognition of an acutely pointed object; further pressure adds to this a sensation of pain. It is almost impossible to prevent the patient saying he is pricked, whenever he appreciates that the stimulus is a sharp point, and, if he is told to wait until he obtains a distinct sensation of pain we run the risk of placing the threshold too high."

From this Head argued that in cases of so-called hypoalgesia from cortical lesions it was the " sense of point," a discriminative faculty, that was lost and not pain sense. Though these two elements may be concerned in any pin-prick it is easy to ascertain from testing colleagues that it does not require a very heavy thrust to ensure that both the " sense of point" and painful elements are called into action. In the present series of tests care has always been taken in confirming an area of pain loss to thrust very heavily. Comparable thrusts on the opposite side raised strenuous objection from the patients.

A further test for pain which has also been employed is entirely free from such objections. Kellgren (1938a and 1938b) in his studies on deep pain found that the injection of hypertonic sodium chloride was a convenient method of producing pain in deep structures. The injection into muscles of $0.2 \mathrm{ml}$. of $6 \%$ sodium chloride has been used in these studies. Once the needle is removed there is no complicating factor and a pure pain stimulus is produced. The pain is quite severe, and there is no possibility of doubt or confusion in comparing a normal and a hypoalgesic area. It is contended, therefore, that in this series we have cases of cortical damage which are free from the objections discussed above.

In examining the records of so large a series of penetrating wounds a remarkable feature is the striking, dissociated sensory losses which have been observed. Not infrequently position sense would be entirely normal but severe impairment of 2-point discrimination would occur and vice versa. These findings appear surprising to those more accustomed to observing the sensory changes wrought by the progress of natural disease, for here discrete, permanent, dissociated sensory deficits are the exception rather than the rule.

These features are illustrated in Series $C$ where two examples of dissociation between pain and temperature sense are presented. In Case 14 deep and superficial pain were quite normal, whilst temperature appreciation was almost lost, and in Case 15 there was appreciable delay. These cases illustrate that not only can dissociation of discriminative sensibilities occur as a result of cortical wounds but also the so-called thalamic sensations such as pain, temperature, and touch can be separately affected. These illustrations have been included to provide further evidence of how specific in their effects these wounds can be.

Series B consists of two cases of cortical wounding in which there was hyperalgesia, extending in Case 12 over one half of the body and in Case 13 being segmental in distribution. Now though it may be suggestive, nevertheless it is not valid to argue that because a cortical lesion causes hyperalgesia, therefore the convolutions damaged must be the centre for the representation of pain. However, it is valid to suggest that whereas it was formerly considered that hyperalgesia was pathognomonic of a lesion confined to the thalamus, it appears that this so-called thalamic symptom of excessive response to painful stimuli may be produced by cortical lesions.

The Series A cases need no elaboration as far as $\stackrel{\overrightarrow{0}}{\infty}$ the facts are concerned. The patients had pain $\frac{\rho}{1}$ 윽 impairment both superficial and deep and theiro lesions were cortical in site. Series D illustrates $\square$ the anomaly mentioned by Russell (1945) that 0 c whereas extensive cortical injury can leave paino क sensibility intact, a small cortical wound may impair pain sensation on the contralateral side. These cases conformed to the classical neurological description of the effects of cortical lesions. They had more extensive wounds, yet though position sense and 2-point discrimination were impaired, pain sensibility remained unaffected. It remains, therefore, to try to construct a hypothesis to explain these facts.

Le Gros Clark (1932) showed that degeneration of the thalamus follows ablation of the cortex, thereby stressing the importance of cortico-thalamic projections, which, as McCulloch (1944) has shown, are most dense from the posterior lip of the central fissure. Dusser de Barenne and McCulloch (1938), by their method of neuronography, showed that while strychninization of a small area of the thalamus produced spikes in a wider area of the sensory cortex, symptoms were only referred to that part of the body represented by the part of the thalamus initially stimulated. A feed-back was established from the cortex to the thalamus which raised the excitation of the already stimulated thalamic cells to a level sufficient to produce a sensation. Other thalamic areas, not being already 
in a state of excitation as a result of afferent stimuli from the periphery, did not achieve a liminal degree of excitation as a result of feed-back from the wider stimulated cortical area. Thus we see established from both anatomical and physiological viewpoints the close mutual relationship between cortex and thalamus, a partnership on equal terms, rather than the former concept of cortical dominance.

As a result of these various contributions the idea of an impulse passing from the periphery to the thalamus and thence to the cortex from where a circuit back to the thalamus again becomes established, arose. It matters little for our present purpose whether with Bremer and Bonnet (1949) we think that the main circuits are intracortical and it is not until these have been built up that the thalamus is finally fired, or whether with Chang (1950) we consider that these reverberating circuits lie exclusively between cortex and thalamus. The essential fact is that the final elaboration of the sensory impulse depends on mutual activation of thalamus and cortex.

Now as Earl Walker (1949) has pointed out, the mode of establishment of these circuits is by mechanisms such as recruitment, facilitation, and summation common to neuron pools throughout the nervous system. The agents which transmit excitation or inhibition to a neuron are the boutons terminaux which are in contact with its surface. The resultant of the excitatory and inhibitory influences determines the activity of the cell. Liddell (1934) showed that in a spinal cord lesion the impulses delivered by many such boutons are cut off at their source and hence the receptor neuron, until it can readjust to the changed conditions of activity, ceases to function. This condition is spoken of as the period of spinal shock.

It is pertinent to note, as Russell (1945) has pointed out, that even following small cortical wounds with no disturbance of consciousness pain sensibility is often lost for several days but ultimately it recovers. He suggested that this was a shock effect of the type described by Liddell (1934). In the terms of the observations described above this "shock" effect can be conceived as affecting the cortico-thalamic circuits which are essential for the conveyance of sensation to consciousness. In many cases these circuits are able to readjust and re-establish themselves and pain sensibility recovers. In other cases, however, such as those presented in this study, the damage to these circuits at their cortical end is such as to preclude their re-establishment and hence pain loss becomes a permanency.

Why then, when wider areas of cortex are destroyed does pain often recover? As was pointed out above, stimulation of a group of thalamic cells fires a much wider area of cortex (Dusser de Barenne and McCulloch, 1938) but symptoms are only referred to that part of the body subserved by the part of the thalamus originally stimulated which has been fed-back from the reciprocal area of the cortex. The remaining cortico-thalamic circuits produce no effects. They do, however, constitute a net in which the impulse may expend itself, albeit fruitlessly, when it is blocked from its primary pathway. When, however, cortical damage, and hence thalamic degeneration, is widespread such pathways are no longer available and the impulses may then be passed to the contralateral corticothalamic circuits and pain is felt.

Why then do the discriminative aspects of sensibility not undergo similar re-adjustments? The reason is perhaps but an illustration of Hughlings Jackson's law that the higher and more specific aspects of any function are the first to be affected, the last to recover, and the least capable of effecting any re-adjustment. In physiological terms, as described by von Bonin (1950), the complexity of the nerve net required to subserve discriminative functions is so great as to make alternative pathways difficult. The more primitive sensations on the other hand have more simple nets and can more readily utilize alternative routes.

In conclusion, therefore, it may be asked, "Is pain represented in the cortex" ? If by representation we mean an end-station or a highest level as was meant by Head, it must be answered, "No". If, however, we mean, "Is the cortex concerned in the appreciation of pain "? it is submitted that the cases presented here show that the cortex is intimately concerned with appreciation of pain and the hypothesis is offered as an explanation in conformity with modern neurophysiological concepts.

\section{Summary}

The historical development of the current view with regard to the central representation of pain is described.

Eleven cases of cortical wounds with impairment of pain and temperature sense are described.

Two cases of cortical wounds with persistent hyperpathia are presented.

Two examples of small cortical wounds with impairment of temperature sense but preservation of pain sensibility are recorded.

Two cases of extensive wounds with loss of discriminative sensation but with pain sense preserved are described.

It is suggested that the cerebral cortex is concerned with pain sensibility; and a hypothesis to explain the paradox, that whilst small cortical 
wounds may affect pain larger wounds often do not, is presented.

I wish to thank Dr. W. Ritchie Russell for his kindness in granting me access to the records of the Head Injury Advice Bureau and for permission to examine the patients ; also to Miss Martin-Hurst, Almoner at the Bureau, without whose personal knowledge of and tactful approach to the patients, it would not have been possible to persuade so many of them to return for re-examination. I also wish to thank Dr. Fergus R. Ferguson for permission to quote Case 18.

In addition tribute must be paid to the many neurologists and neurosurgeons, without whose careful observations and meticulous records, made often under difficult conditions in the field, so fine a series of cases would not have been preserved, and this study would not have been possible.

Finally I wish to thank Brigadier W. R. D. Hamilton, O.B.E., Consultant Physician, the War Office, for permission to publish.

\section{REFERENCES}

Birt, C. (1904). Brit. med. J., 1, 598.

Bonin, G. von (1950). "Essay on the Cerebral Cortex." Springfield, U.S.A.

Bremer, F., and Bonnet, V. (1949). Electroenceph. and clin. Neurophysiol., 1, 447.

Campbell, A. W. (1905). "Histological Studies on the Localisation of Cerebral Function." Cambridge.

Chang, H. T. (1950). J. Neurophysiol., 13, 235.

Clark, W. E. Le Gros (1932). Brain, 55, 406.

Cushing, H. (1909). Ibid., 32, 44.

Davison, C., and Schick, W. (1935). Arch Neurol. Psychiat., Chicago, 34, 1204.

Dejerine, J., and Mouzon, J. (1915). Rev. Neurol., 28, 1265.
Dusser de Barenne, J. G., and McCulloch, W. S. (1938). J. Neurophysiol., 1, 69.

Ferrier, D. (1886). "The Functions of the Brain," 2nd ed. London.

Gowers, W. R. (1901); “"Epilepsy and Other Chronic Convulsive Diseases," 2nd ed. London.

Guillain, G., and Bertrand, I. (1932). Ann. Med., 31, 35.

Head, H. (1920). "Studies in Neurology." London. , and Holmes, G. (1911). Brain, 34, 102.

Hitzig, E. (1900). Ibid., 23, 545.

Horsley, V. (1909). Brit. med. J., 2, 125.

Holmes, G. (1927a). Lancet, 1, 957.

-(1927b). Brain, 50, 413.

Kellgren, J. H. (1938a). Clin. Sci., 3, 175. (1938b). Brit. med. J., 1, 325.

Kleist, K. (1922). In "Handbuch der ärztlichen Erfahrungen im Weltkriege." ed. O. von Schjerning, vol. 4. Leipzig.

Liddell, E. G. T. (1934). Brain, 57, 386.

Michelsen, J. J. (1943). " "Pain." Res. Publ. Ass. Nerv. Ment. Dis., 23, 86.

McCulloch, W. S. (1944). Physiol. Rev., 24, 390.

Mott, F. W. (1894). J.P Physiol., Lond., 15, 464.

Munk, H. (1892). "Ueber die Fuhlsphaeren der Grosshirnrinde." Berlin.

Peele, T. L. (1944). J. Neurophysiol., 7, 269.

Penfield, W., and Boldrey, E. (1937). Brain, 60, 389.

- and Gage, L. (1933). Arch. Neurol. Psychiat., Chicago, 30, 709.

Piéron, H. (1923). " Le Cerveau et La Pensée." Paris.

Russel, C. K., and Horsley, V. (1906). Brain, 29, 137.

Russell, W. R. (1945). Ibid., 68, 79. (1947). Ibid., 70, 225.

Schäfer, E. A. (1898). J. Physiol., Lond., 23, 310.

Smyth, G. E., and Stern, K. (1938). Brain, 61, 339.

Souques, A. (1921). Rev. Neurol, 37, 984.

Walker, A. E. (1943). " Pain." Res. Publ. Ass. nerv. Ment. Dis. 23, 63.

451 .

Wilson, S. A. K. (1927). Brain, 50, 428. 